\title{
Three-dimensional ultrasonography by means of HDlive rendering in the first trimester of pregnancy: A pictorial review
}

\author{
Gabriele Tonni ${ }^{1}$, Anna Pia Castigliego ${ }^{1}$, Gianpaolo Grisolia ${ }^{2}$, Mario Lituania ${ }^{3}$, Simon Meagher ${ }^{4}$, Fabrício Da Silva Costa ${ }^{4,5}$, \\ Edward Araujo Júnior ${ }^{6}$ \\ 'Department of Obstetrics and Gynecology, Prenatal Diagnostic Service, Guastalla Civil Hospital, AUSL Reggio Emilia, Italy \\ ${ }^{2}$ Department of Obstetrics and Gynecology, Prenatal Diagnostic Service, "Carlo Poma" Hospital, Mantua, Italy \\ ${ }^{3}$ Department of Obstetrics and Gynecology, Preconceptional and Prenatal Medicine, IRCCS Gabbliera Hospital, Genoa, Italy \\ ${ }^{4}$ Monash Ultrasound for Women, Melbourne, Victoria, Australia \\ ${ }^{5}$ Department of Perinatal Medicine, Royal Women's Hospital and Department of Obstetrics and Gynaecology, University of \\ Melbourne, Melbourne, Australia \\ ${ }^{6}$ Department of Obstetrics, Federal University of São Paulo and Paulista School of Medicine, São Paulo, Brazil
}

\section{Abstract}

\begin{abstract}
Our objective was to describe early embryo/fetus anatomy and abnormalities provided by three and four-dimensional (3D/4D) ultrasound using HDlive rendering technology in the first trimester of pregnancy. Normal and pathologic embryonic and fetal volume data set with postprocessing using HDlive rendering mode. Virtual fetoscopic imaging of the normal and pathologic fetus even at early stage of development with increasing maternal-fetal bonding process. HDlive represents a novel and valuable lightening system for 3D/4D ultrasound application that may aid the prenatal interpretation of early congenital malformations although limitations and cautions are still needed for inclusion in obstetric clinical practice. (J Turk Ger Gynecol Assoc 2016; 17: 110-9)
\end{abstract}

Keywords: First trimester of pregnancy, fetal malformations, three-dimensional ultrasound, HDlive rendering

Received: October 16, 2015 Accepted: January 22, 2016

\section{Introduction}

Ultrasonography is the leading examination for the detection of fetal abnormalities during pregnancy, particularly in the second and third trimesters. Over the last 15 years, threeand four-dimensional $(3 \mathrm{D} / 4 \mathrm{D})$ ultrasound has undergone dramatic technical improvements resulting in an enhanced diagnostic accuracy of ultrasonography in daily obstetrics practice (1). The technical advancement of 3D/4D ultrasound includes the improved evaluation of complex anatomical structures using the multiplanar approach (2) or volumetric measurements of fetal organ by means of virtual organ computer-aided analysis (3). In addition, anatomical details can be reformatted using the Omniview technique (4-6) and surface analysis of minor defects can be performed using the newly developed lightening technique called High Definition live (HDlive) $(7,8)$.
The estimated fetal weight can be enhanced by means of 3D ultrasound, and an angiographic study using Doppler ultrasound can be applied to the study of placental function, namely placental biopsy (9), to improve the antenatal diagnosis and to detect intrauterine growth restriction. Hence, the application of 3D/4D ultrasound has been proven to have contributed to an increased diagnostic accuracy when applied to the study of the central nervous system (neuroscan), cardiac anatomy, and orofacial malformations $(10,11)$. The introduction of the HDlive rendering offers a natural and realistic view of the fetus through the use of a new skin-like color (12) that makes the ultrasound images more discernible to both parents and clinicians than those obtained by conventional two-dimensional (2D) or 3D ultrasound. HDlive rendering can be applied during the entire pregnancy duration, although more natural and realistic views of the fetus are obtained when scanning in the first trimester. In this pictorial review, we aim to present our series of normal and pathologic embryo-fetus development by means of HDlive rendering. 


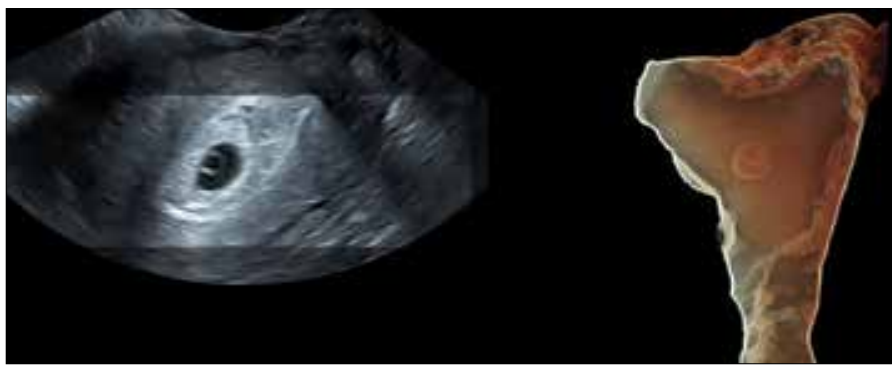

Figure 1. Topic gestation of 5 weeks using the HDlive rendering in the silhouette mode

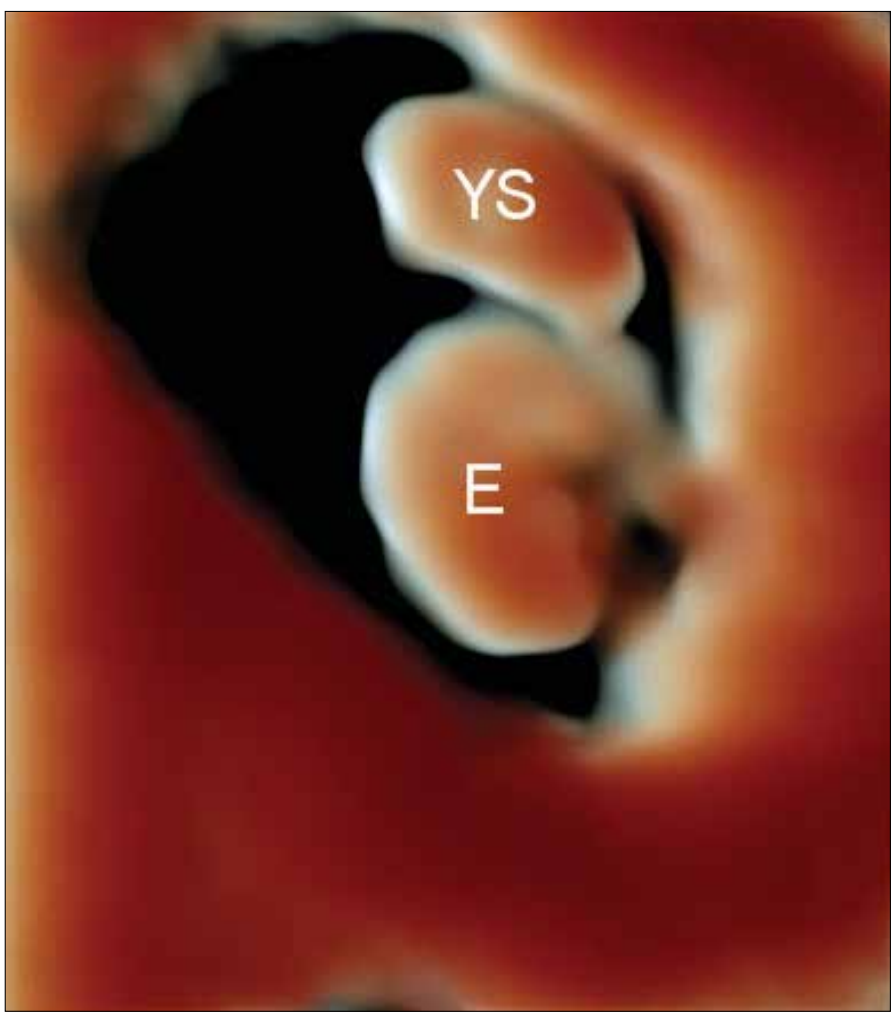

Figure 2. HDlive showing a single normal embryo and yolk sac at 6 weeks 6 days of gestation. YS: yolk sac; E: embryo

\section{Methods}

We conducted a retrospective cross-sectional study that involved four reference centers of prenatal diagnosis (Guastalla Civil Hospital; AUSL Reggio Emilia, Italy; "Carlo Poma" Hospital; Mantua, Italy; IRCCS Galliera Hospital, Genoa, Italy; and Monash Ultrasound for Women; Melbourne, Victoria, Australia). Normal and pathologic embryos/fetuses detected in the routine first trimester scan using 3D/4D ultrasound were reviewed from their database. This study was approved by the Local Ethic Committee from these institutions. Ultrasound examination was performed using a Voluson E8 apparatus (General Eletric, Healthcare; Zipf, Austria) (Guastalla Civil Hospital, AUSL Reggio Emilia, "Carlo Poma" Hospital; Mantua, Italy; and IRCCS Galliera Hospital; Genoa, Italy) and a Voluson E10 [Monash Ultrasound for Women; Melbourne, Victoria, Australia (GE; Milwaukee, WI; USA] equipped with transabdominal volumetric RAB4-8L and

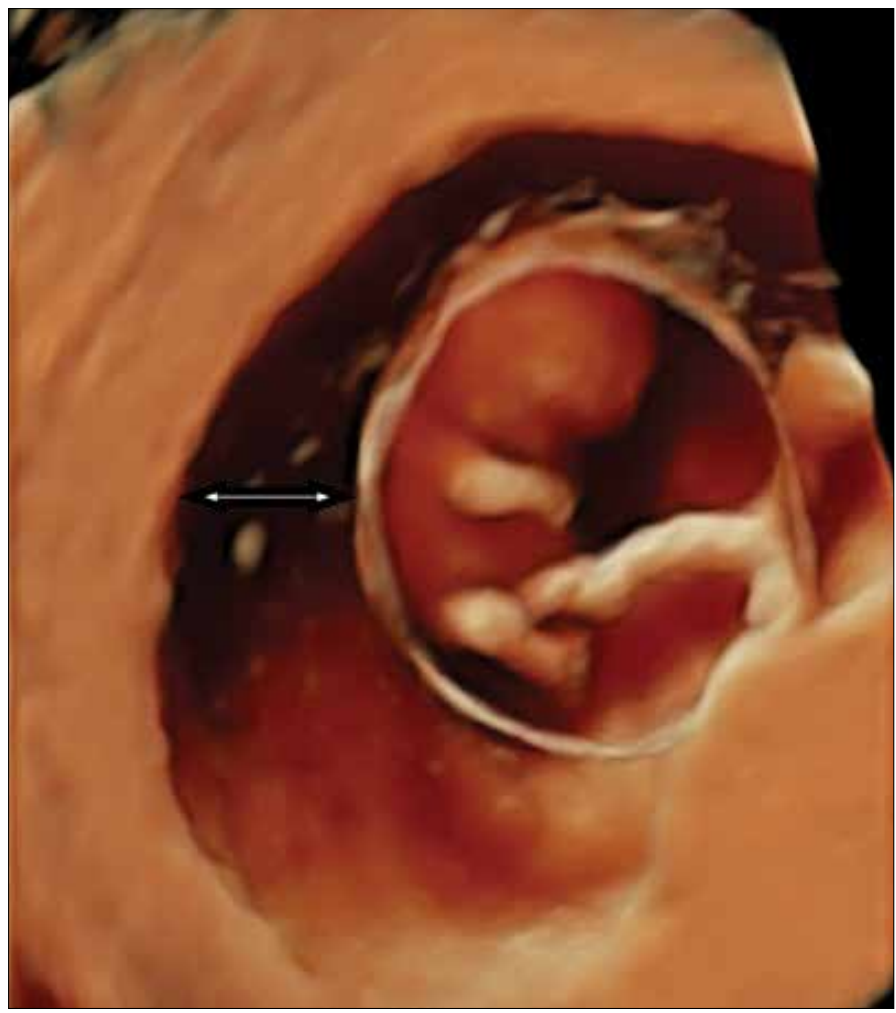

Figure 3. Fetus at 9 weeks 1 day of gestation. The extracelomic cavity is clearly seen (double arrow). HDlive has the potential to enhance visualization, aiding an invasive procedure such as transvaginal celocentesis performed for early embryo-fetal karyotyping

transvaginal RIC5-9W volumetric probes. All examinations were performed by four experienced sonographers in 3D/4D ultrasonography. Ultrasound volume was acquired during maternal apnea and fetal resting to reduce motion artifacts. Volume data set was acquired using the 3D static mode and was stored in an optical disk for subsequent post-processing offline analysis using the 4D view software version 13.0 (General Eletric, Heathcare; Zipf Austria).

The volume data set underwent post-processing analysis using HDlive rendering. All embryos/fetuses with malformations were followed until delivery and/or termination of pregnancy, and the prenatal diagnosis was confirmed on physical examination, diagnostic imaging, or autopsy.

\section{Results and Discussion}

The HDlive mode is a recently developed technique for 3D/4D ultrasound that provides a natural and anatomically realistic appearance of the normal embryo/fetus and that can represent a diagnostic improvement in pathologic cases, particularly during the first trimester of pregnancy. HDlive has been proven to be useful not only for the examination of surface details due to its "humanized" rendering but also for imaging of the umbilical cord and amniotic membranes. The application of HDlive to normal embryo-fetal development from 6 to 12 weeks of gestation is depicted in Figures 1-4. The morphology of the yolk sac can be easily identified in normal and in pathological cases (13). Furthermore, at 12 weeks of gestation, HDlive offers 

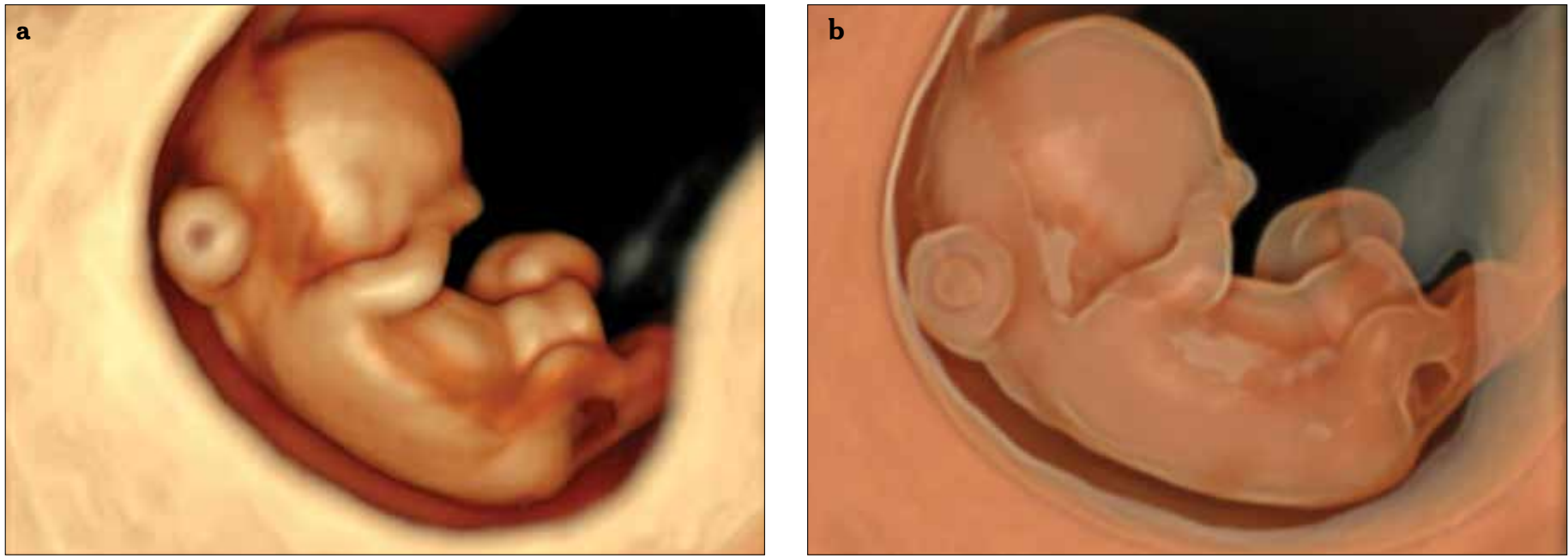

Figure 4. a, b. HDlive rendering mode of fetus at 10 weeks 2 days of gestation (a). Image obtained using the silhouette mode (b).

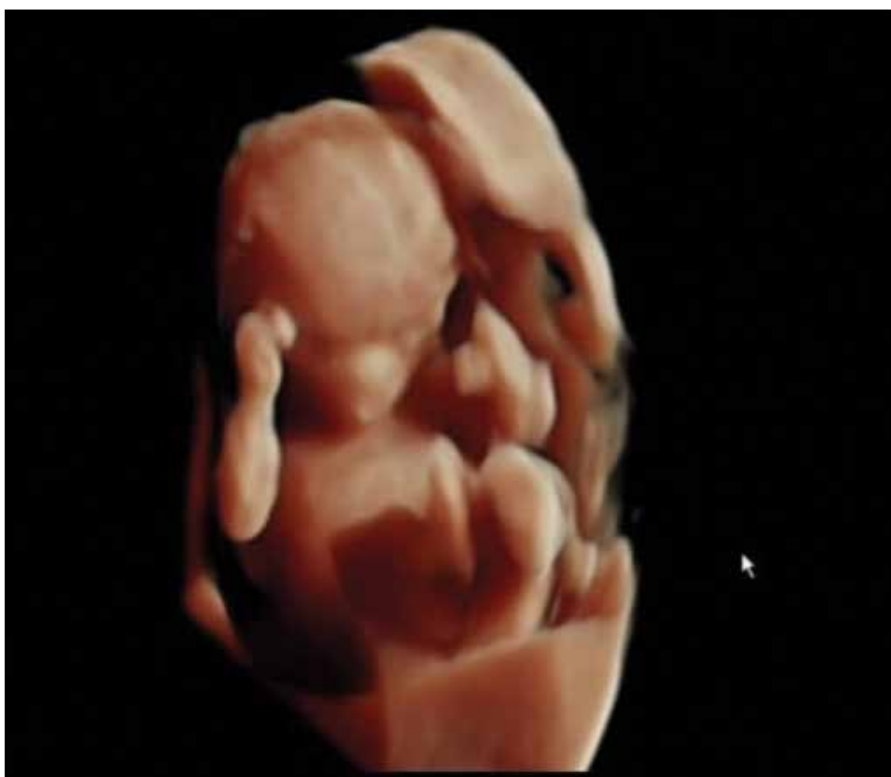

Figure 5. HDlive rendering mode of a normal fetus at 12 weeks of gestation

a clear-cut image of the superficial and small structures such as lips, eyelid, and ears or of extremities such as fingers in a manner that resembles a "virtual fetoscopy" (Figure 5). BonillaMusoles et al. (14) have demonstrated the role of HDlive when applied to fetuses at $<16$ weeks of gestation. Normal and abnormal placentas, similar to those observed in fetal hydrops, or placental shelf (and protruding into the amniotic cavity), subchorionic maternal lakes, or umbilical cord anomalies such as cord entanglement, cord cyst, and varix can be well identified by this novel lightening technique (15). Kanenishi et al. (16) have described a case of intra-amniotic umbilical vein varix with thrombosis at 35 weeks of gestation. The HDlive rendering clearly demonstrated a fragile massive thrombosis inside the varix. A histological examination performed after delivery proved the prenatal diagnosis. Recently, AboEllail et al. (17) described a case of circumvallate placenta at 16 weeks 5 days of

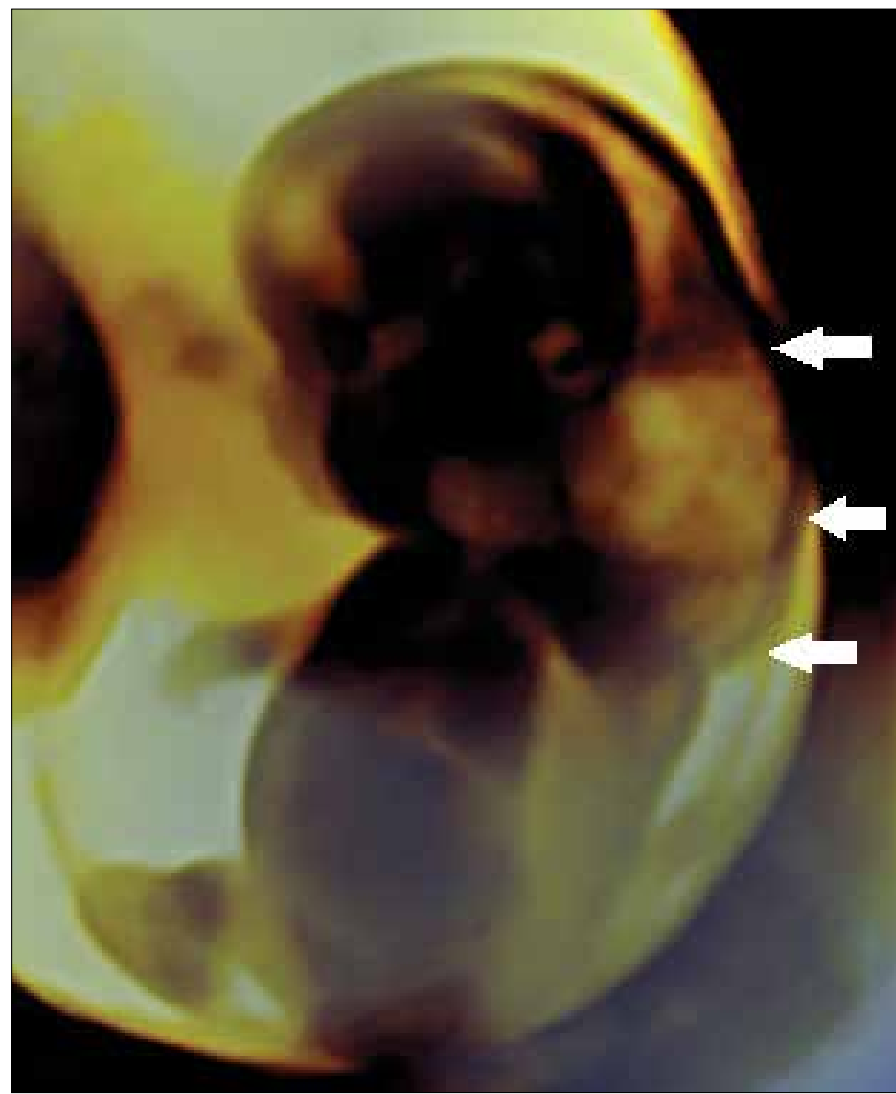

Figure 6. HDlive rendering mode of a fetus at 10 weeks 2 days of gestation showing a cystic hygroma (white arrows)

gestation using HDlive rendering in the silhouette mode. HDlive in the silhouette mode depicted the thickened, curved edges of the placenta and the central depressed region to which the umbilical cord was attached. The macroscopic examination of the placenta after delivery confirmed the prenatal diagnosis associated with a true knot of the umbilical cord. Furthermore, AboEllail et al. (18) have described the used of HDlive in a case of giant fetal hemangioma. 

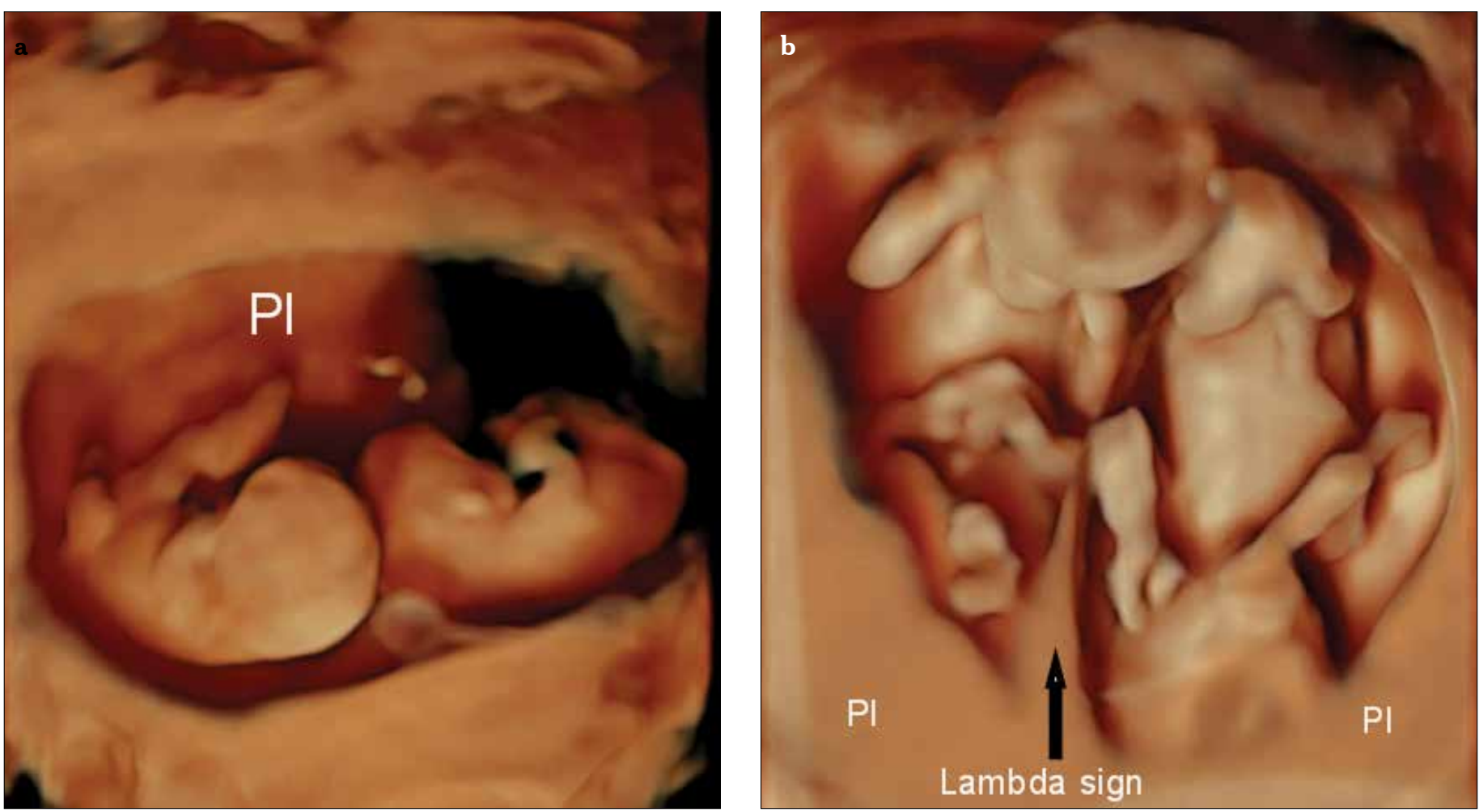

Figure 7. a, b. Monochorionic monoamniotic twins at 11 weeks 2 days of gestation (a) and dichorionic diamniotic twin pregnancy at 13 weeks of gestation. The "lambda sign" is clearly visible (b)

Two articles have reported on sonographic imaging of a normal embryo and fetus, and an abnormal fetus, placenta, and umbilical cord using 3D HDlive in the rendering mode $(19,20)$. HDlive may be superior to normal 2D ultrasound in the characterization of a chorionic bump, which is an irregular convex bulge passing from the choriodecidual surface into the first-trimester gestational sac. A chorionic bump may clinically represent a warning sign when detected in the first trimester scan as women with such an ultrasound marker have almost double the risk of miscarriages compared with controls $(15,21,22)$. A cystic hygroma is highly defined using this lightening technique as can be seen in Figure 6 . This finding has also been reported by Hata et al. $(23,24)$.

Pooh and Kurjak (10) have demonstrated that HDlive rendering easily allowed the image of ear position in the first trimester and also the documentation of feet/toe morphological abnormalities not only in the first trimester but also in various foot/toe appearances such as sandal gap, hypertonic contracture, foot edema, and rocker bottom feet in the second trimester.

In addition, HDlive can be used in multiple pregnancy with a clear definition of the "lambda sign" while evaluating chorionicity (Figure 7). Currently, only two cases of prenatal 3D ultrasound diagnosis of the twin reversed arterial perfusion (TRAP) sequence in the first trimester (at 11 weeks and 4 days and at 13 weeks) have been described (25-27). In these two cases, conventional 3D ultrasound assisted in confirming the diagnosis and evaluating the extent and severity of structural anomalies in the acardiac fetus. Notwithstanding, near-fetoscopic images of the TRAP sequence in the first trimester were obtained by em- ploying the 3D HDlive rendering mode. In particular, 3D HDlive rendering images of the acardiac fetus seemed to be more readily discernible than those obtained by $2 \mathrm{D}$ and conventional 3D sonography because the 3D HDlive rendering provided a natural and anatomically realistic appearance of the acardiac fetus (25-27).

HDlive has been shown to improve our understanding of neurobehavioral development in twins and assist in the investigation of inter-twin temperament and relationship $(28,29)$. It can aid the prenatal diagnosis of orofacial malformations such as cleft lip as it enables enhanced anatomical details of the facial surface and structures even at a very early stage of embryo-fetal development (Figure 8). HDlive may be the diagnostic investigation and supplement conventional 2D/3D ultrasound in cases of acrania/ exencephaly (30) or in case of minor or subtle fetal face abnormalities such as flattened nose and broad nasal bridge $(31,32)$ or be highly illustrative in case of severe midline defects $(33,34)$, particularly when surface rendering of the fetal face is applied after 28 weeks of gestation (34). Again, abdominal wall defects such as exomphalos and gastroschisis are well documented and illustrative (Figure 9, 10). The snapshot of digit aplasia, which is not easy to demonstrate, using conventional 2D/3D ultrasound, has been clearly defined (Figure 11). Nonetheless, the diagnostic enhancement of HDlive may allow the early detection of characteristic abnormal phenotypes such those observed in common trisomy and/or in syndromic fetuses (32) (Figure 12). HDlive allowed obtaining an extraordinary image quality in a case of sirenomelia, a midline defect of blastogenesis with an incidence of approximately 1 in 60,000 newborn infants. Sirenomelia results 

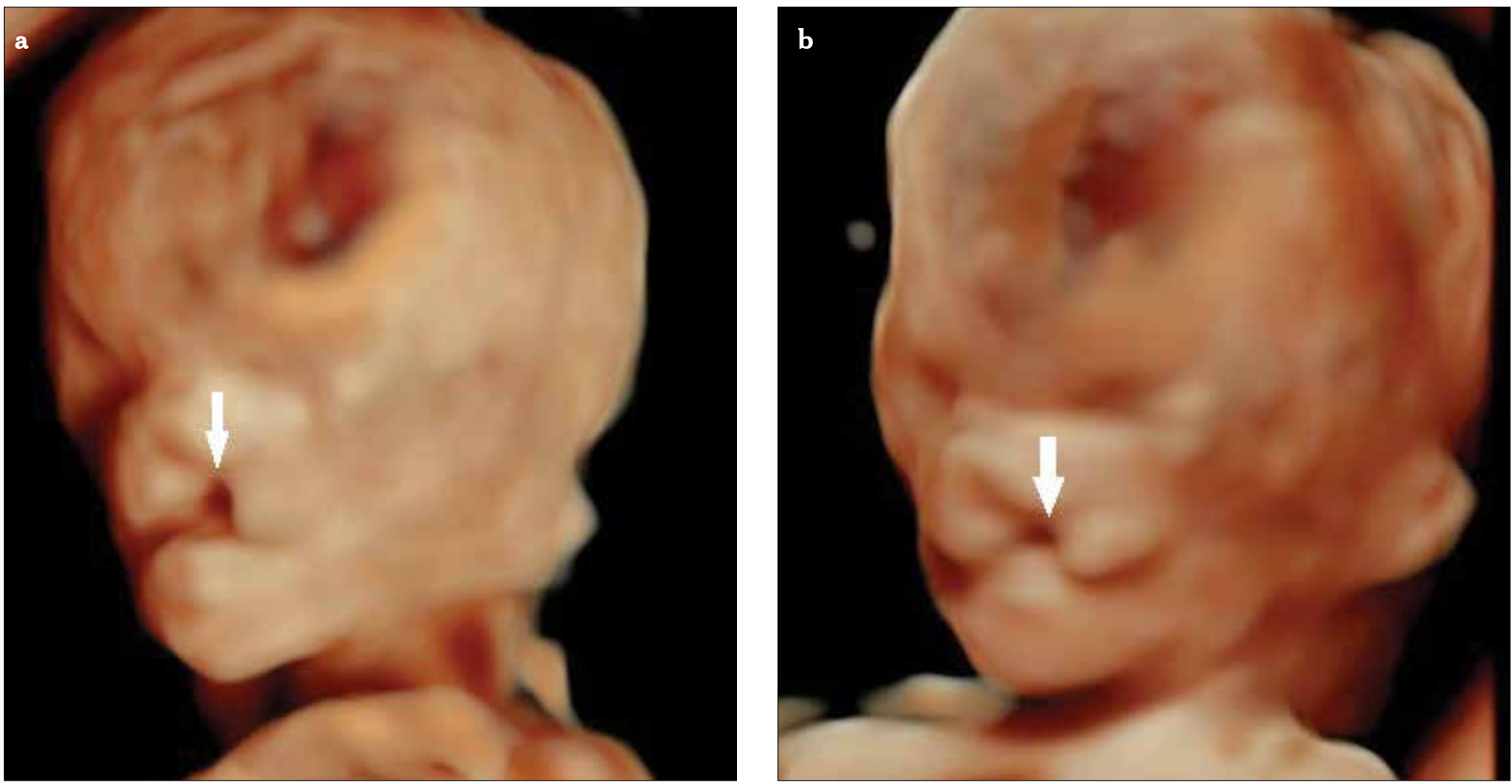

Figure 8. a, b. HDlive rendering mode in a fetus at 13 weeks of gestation presenting (a) median and (b) left cleft lip (white arrows)

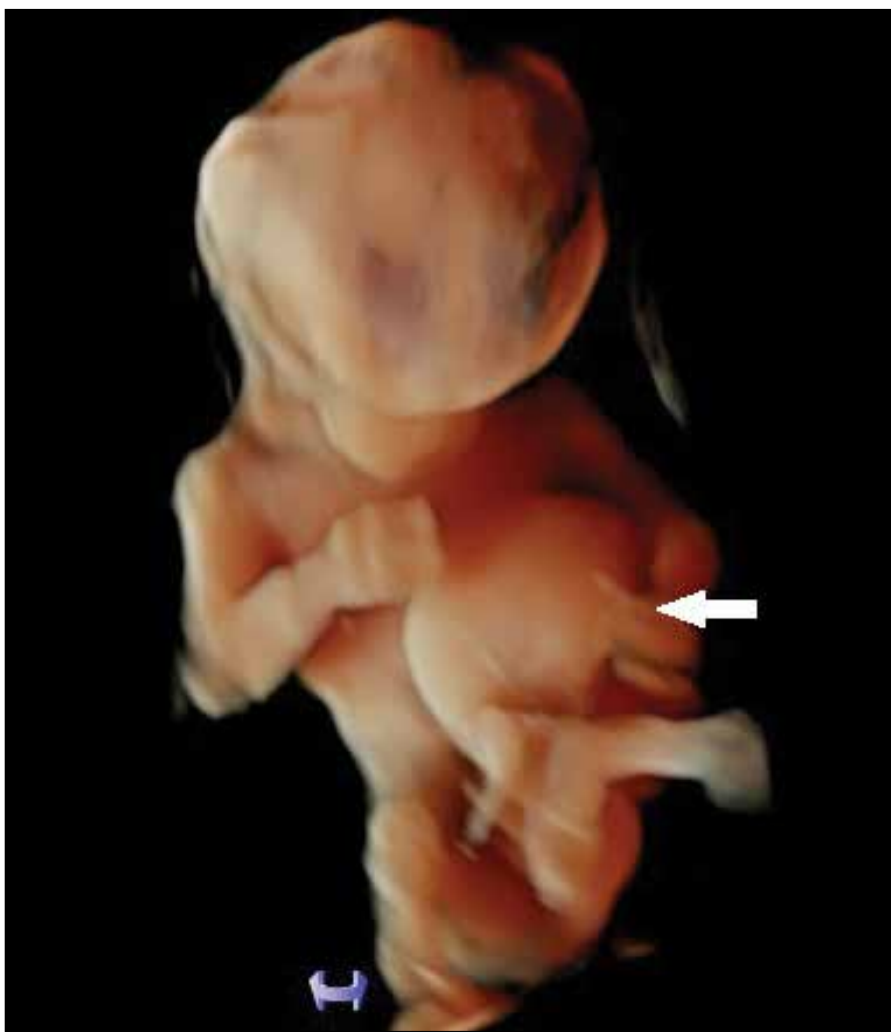

Figure 9. HDlive rendering mode in a fetus at 13 weeks of gestation with exomphalos (white arrow)

in a severe developmental defect of the posterior axis caudal blastema occurring in the primitive streak stage during week 3 of gestation (35). In this pictorial review, we report our case of a

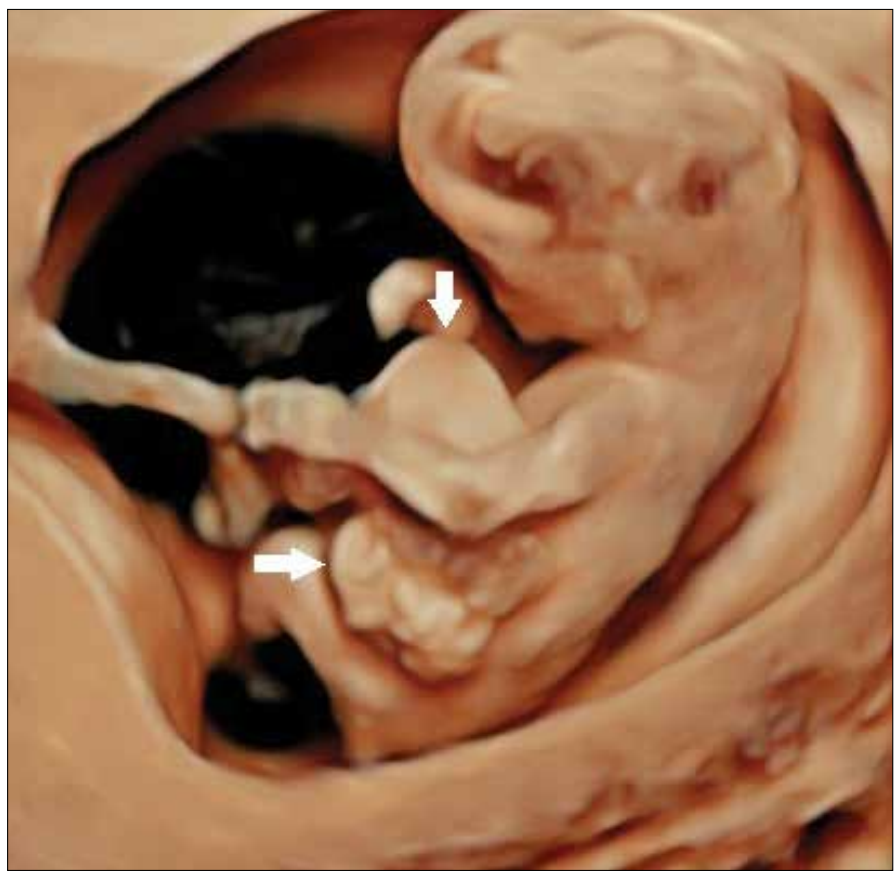

Figure 10. HDlive rendering mode in a fetus at 13 weeks of gestation with gastroschisis (white arrows)

fetus with sirenomelia showing single femur, fused lower limbs, and a single inverted foot with oligodactyly (sympus unipus) (36) that was diagnosed at 12 weeks 1 day of gestation in a fetus with a 46, XX karyotype. A single umbilical artery directly originating from the aorta and a caudal "tail" were the associated ultrasound findings (Figure 13). HDlive has been shown to perform well even in case of skeletal dysplasia in a fetus at 12 weeks 1 day of gesta- 

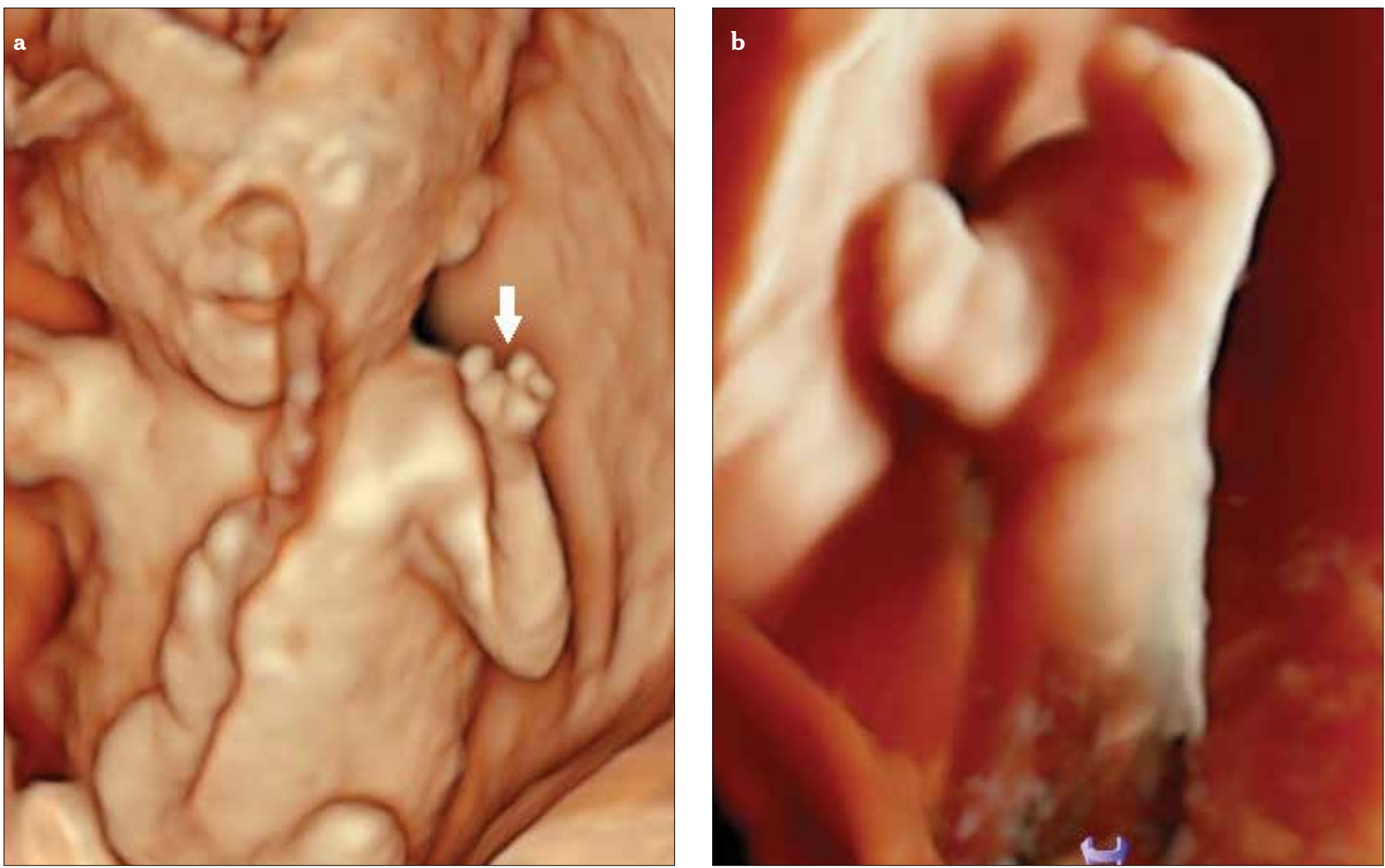

Figure 11. a, b. HDlive rendering in a fetus at 12 weeks 5 days of gestation with unilateral absence of the second and third fingers of the left hand (a) (white arrow). Detail of the left hand (b)

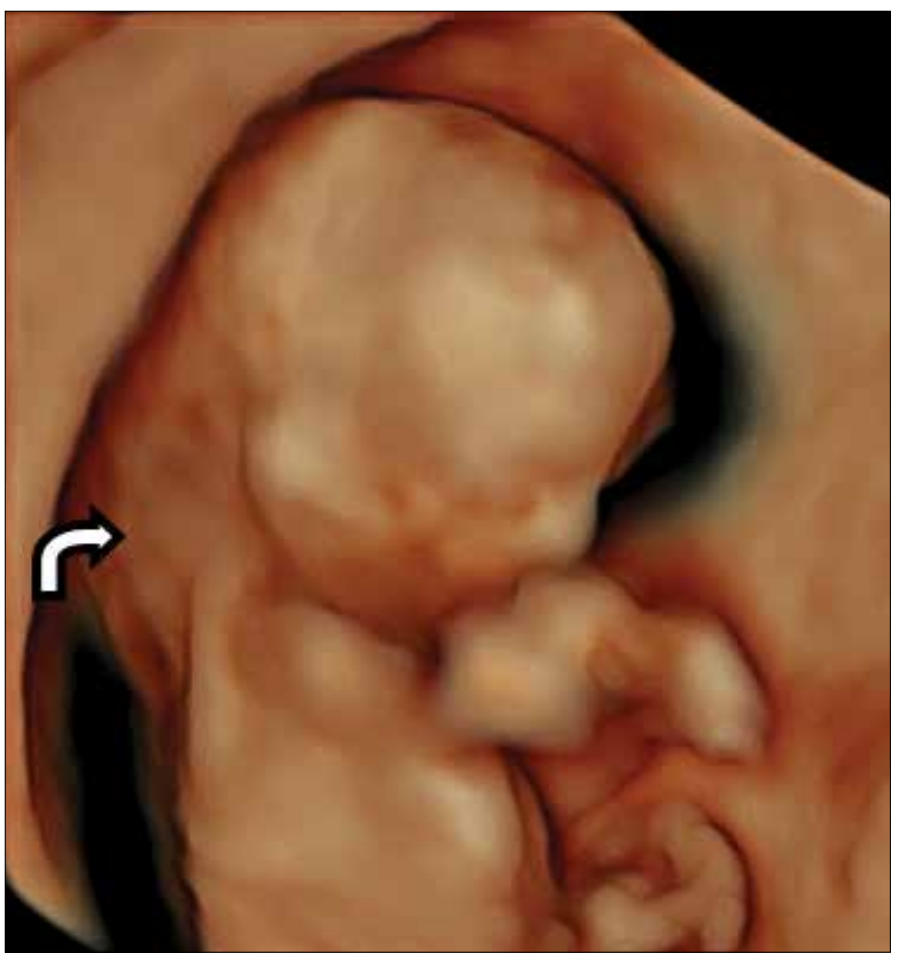

Figure 12. Increased nuchal translucency (curved arrow) in a fetus with trisomy 21 tion presenting with frontal bossing and a flat profile in the 2D scan at the time of the first trimester combined test for common trisomy, where HDlive allowed the better detection of agenesis of the left leg and exadactyly (Figure 14). Furthermore, HDlive has been useful in characterizing a split of the skull base with diplomyelia at the cranial level and an underlying diastematomyelia in a 12 week 2 day fetus with a 46, XY karyotype (Figure 15). Diastematomyelia is a rare form of spinal dysraphism characterized by a sagittal cleft in the spinal cord, conus medullaris, and/or filum terminale with splaying of the posterior vertebral elements (37). The defect may be isolated or associated with myelocele, myelomeningocele, and segmental vertebral body anomalies (38-39).

Moreover, it has been demonstrated that HDlive with spatiotemporal image correlation (STIC) that allows a new realistic image modality of endocardial cushion that may result in diagnostic enhancement in pathologic cases (11). AboEllail et al. (40) have reported the diagnostic value of HDlive in a case of atrioventricular septal defect, bilateral ventricular hypertrophy, and pericardial effusion. HDlive depicted a common atrioventricular (AV) valve and suspected that the free, floating leaflets of $\mathrm{AV}$ valve were not attached to the interventricular septum. Moreover, the contemporary use of STIC allowed the recognition of the anatomical relationship among the common AV valve, chordae, and papillary muscles.

Very recently, Pooh (41) has demonstrated that HDlive greatly improves our angiographic imaging of intracorporeal vessels 

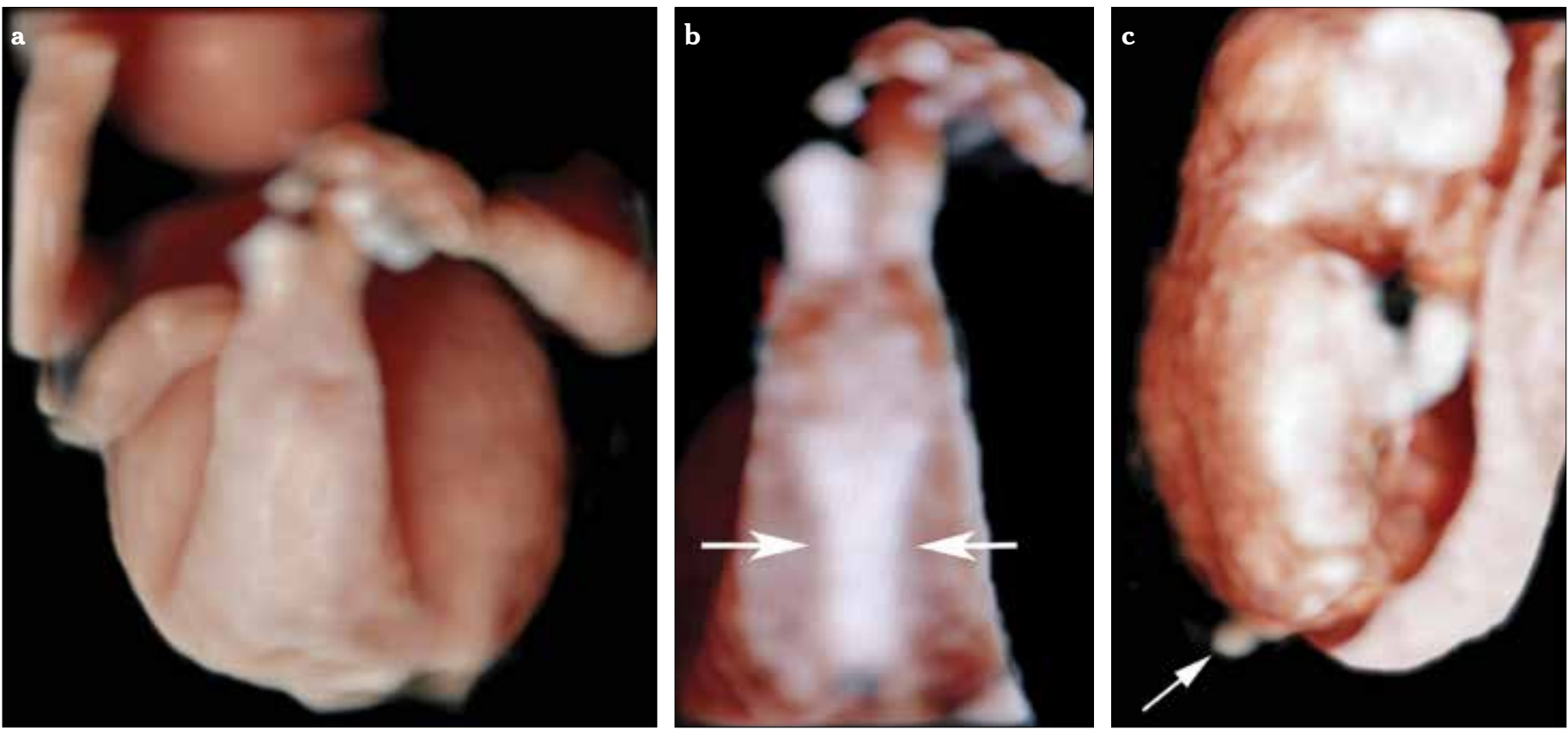

Figure 13. a-c. HDlive rendering showing sirenomelia (a) with single femur, fused lower limbs, and a single supinovarus foot with oligodactyly (symelya unipus) diagnosed at 12 weeks 1 day of gestation in a fetus with a 46, XX karyotype (b). The caudal "tail" was also detected (c) (white arrows)

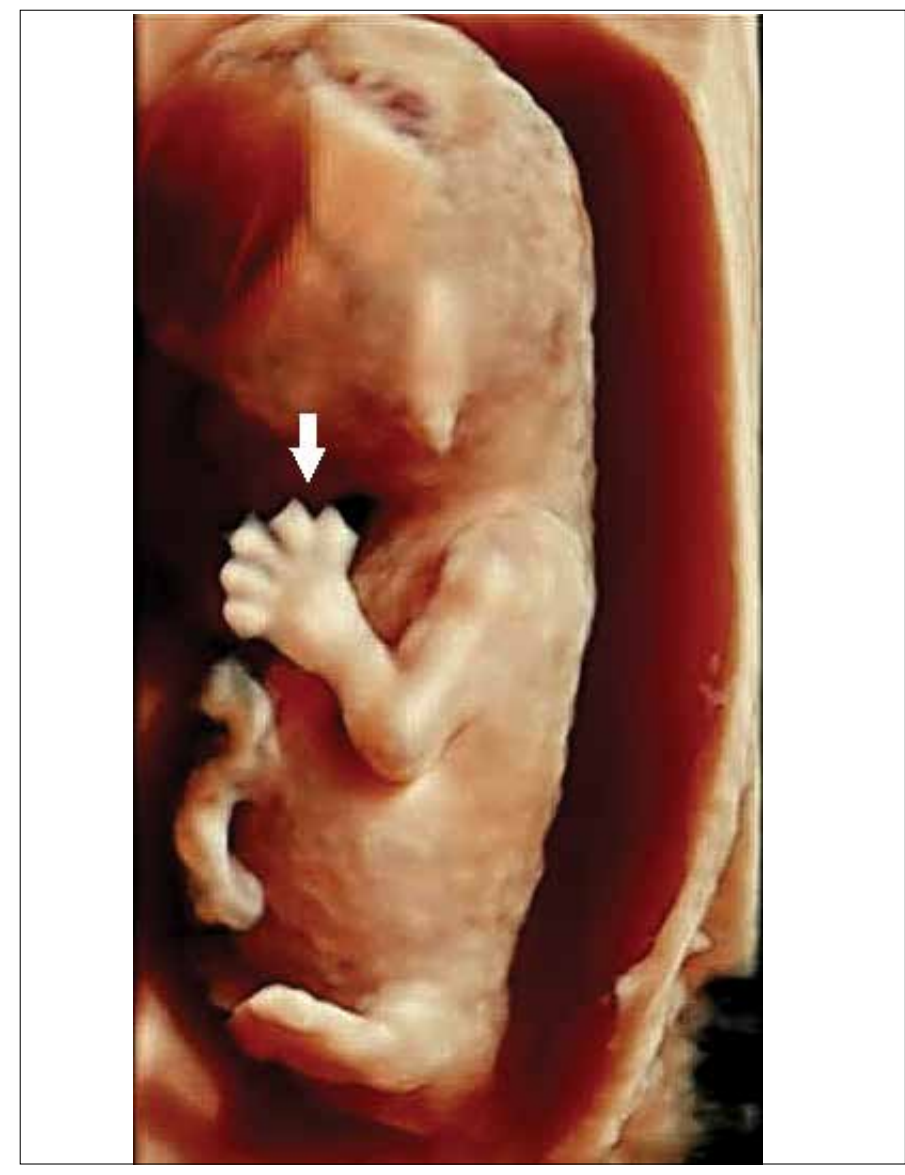

Figure 14. HDlive rendering in a fetus at 12 weeks 1 day of gestation showing skeletal dysplasia characterized by unilateral agenesis of the left leg and exadactyly (white arrow) by demonstrating a rich pulmonary vascularity in a fetus at 13 weeks of gestation using HDlive silhouette/flow imaging with bidirectional power Doppler. Higher advancement in embryologic imaging has been reached by HDlive silhouette/flow mode, a novel developed 3D ultrasound algorithm that creates a gradient on organ boundaries where an abrupt change of the acoustic impedance exists within the tissue. By the HDlive silhouette mode, an inner cystic structure with fluid collection can be seen through the outer surface structure of the body in a "see-through fashion." Hyperechogenic structures such as those forming the skeleton can be extracted with emphasized bony imaging (42). The application of the HDlive silhouette mode or Radiance System Architecture has been proven to greatly contribute to the diagnostic definition in a high number of embryo-fetal malformations as documented by Bonilla-Musoles et al. (43) and AboEllail et al. (44).

The natural appearance of the image as created by HDlive rendering may help create a closer relationship between parents and their children and enhance maternal-fetal bonding. The term bonding is used in the literature to indicate feelings that people have toward their fetus, and through the realistic imaging of the fetus, the HDlive technology seems to increase, maternal and fetal attachment. Fetal blinking, mouthing, swallowing, yawning, tongue expulsion, and sucking are all fetal activities that have been clearly documented using the HDlive rendering mode. Moreover, various realistic fetal emotional expressions such as smiling- and crying-like movements have also been reported with this technique (45).

3D HDlive in the rendering mode has been applied not only to depict superficial anatomical details but also in cases of multycystic dysplastic kidney disease, where it has been shown that the peripheral circular arrangement of the cysts (the so-called 

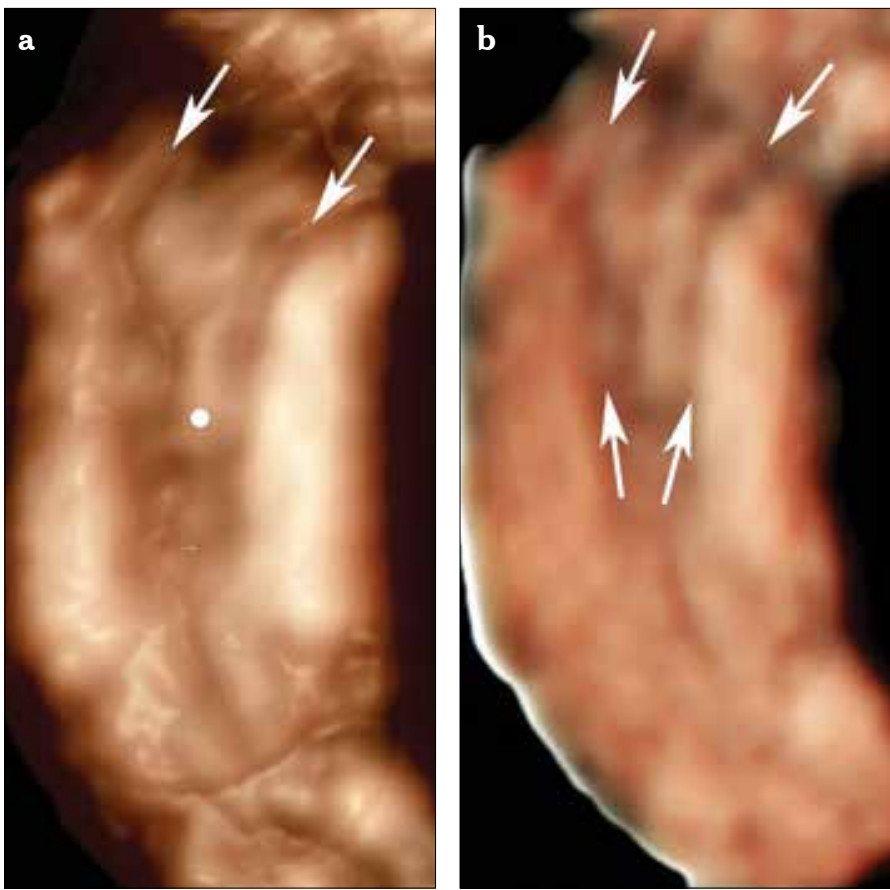

Figure 15. a, b. HDlive rendering of the split of the skull base with diplomyelia at the cranial level (white arrows) (a) and an underlying diastematomyelia (white arrows) (b) in a fetus at 12 weeks 2 days of gestation with a 46, XY karyotype

"necklace appearance") seemed to be more clearly understandable than that obtained by conventional 2D sonography (46).

This observation is in agreement with that by Cajusay-Velasco and Hata. (47) who used HDlive in the assessment of fetal intra-cranial, intra-thoracic, and intra-abdominal anomalies. Notwithstanding, in our series, HDlive has been demonstrated to perform well in a case of a megacyst due to lower urinary tract obstruction during the first trimester scan (Figure 16).

AboEllail et al. (48) have described a meconium peritonitis using HDlive rendering in a primigravida at 32 weeks 2 days of gestation with polyhydramnios and fetal bowel dilatation. HDlive rendering showed that the dilated intestinal loops were irregularly thickened and that there was meconium within the dilated intestine. HDlive with inversion mode rendering clearly showed the continuation between cystic dilatation and the small intestine. The X-ray of the newborn revealed the abdominal calcifications, thus proving the prenatal diagnosis of meconium peritonitis. In another recent case report, AboEllail et al. (49) have described a case of jejunal atresia at 28 weeks of gestation using HDlive using the "silhouette mode". HDlive rendering showed the inner stomach connected by the pylorus to the duodenum and clearly demonstrated the dilated stomach with the absence of peristalsis, while HDlive in the inversion mode identified an excessive duodenal peristalsis.

X-ray imaging performed after delivery documented a triplebubble sign, and gastrografin enema revealed a microcolon. X-ray imaging performed after delivery showed a triple-bubble sign, and gastrografin enema revealed a microcolon. Recently, Kaji et al. (50) demonstrated a case of anorectal atresia in a fetus at 31 weeks 1 day of gestation, showing a normal perineum with the absence of an anal dimple. The postnatal clinical ex-

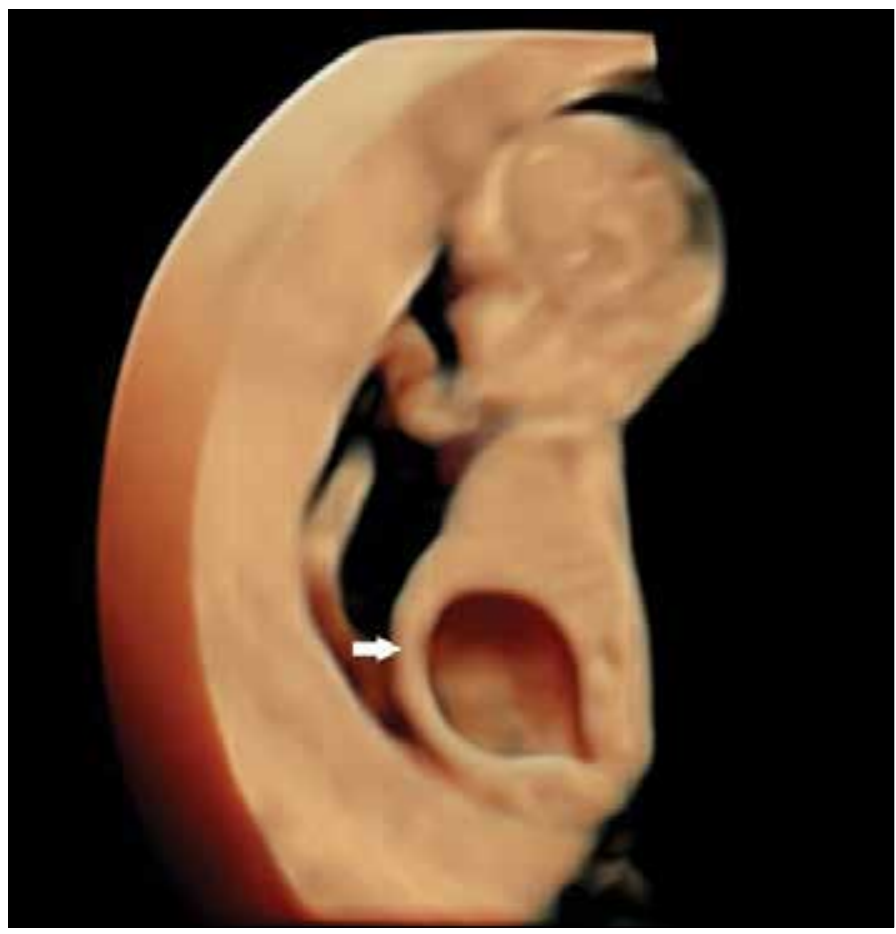

Figure 16. HDlive rendering in a fetus at 13 weeks 1 day of gestation showing a megacyst (white arrow) due to lower urinary tract obstruction

amination result proved the prenatal diagnosis of anorectal atresia with a rectovestibular fistula. X-ray imaging confirmed an intermediate-type of anorectal atresia and esophageal atresia.

Ishibashi et al. (51) used HDlive for the visualization of the bicornuate uterus with hydrometra and bilateral hydrosalpinx in the diagnosis of a persistent cloaca. However, 3D surface rendering and HDlive did not provide unique information for the prenatal diagnosis of persistent cloaca if there was no associated fetal ascites. Although HDlive improves the quality of ultrasound imaging and new developments such as the "crystal view" have been reported (52-54), the true potential of this technique is yet to be scientifically determined (55). There are some limitations in using the HDlive technology that are caused by maternal and embryonic movement that can reduce the image quality. Another limitation is represented by the presence of a small amount of fluid around the embryo and the curvature of the gestational sac (56).

In summary, we demonstrated our experience in the application of HDlive rendering in normal embryo-fetus development and pathologic cases. Our clinical series confirm the previous observation that HDlive rendering generates realistic images by means of an appropriate control of lighting and shadowing effects (54). We believe that HDlive will be incorporated into 3D/4D ultrasound to enhance the sonographic detection of abnormal phenotypes, thus improving parental bonding and genetic counseling.

\section{Ethics Committee Approval: N/A.}

Informed Consent: N/A.

Peer-review: Externally peer-reviewed. 
Author Contributions: Concept - G.T., E.A.J.; Design - G.T., E.A.J.; Data Collection and/or Processing - M.L., G.G.; Analysis and/or Interpretation - A.P.C., F.S.C.; Writer - G.T., E.A.J.; Critical Review - A.P.C., F.S.C.

Conflict of Interest: No conflict of interest was declared by the authors.

Financial Disclosure: The authors declared that this study has received no financial support.

\section{References}

1. Tonni G, Martins WP, Guimarães Filho H, Araujo Júnior E. Role of 3-D ultrasound in clinical obstetric practice: evolution over 20 years. Ultrasound Med Biol 2015; 41: 1180-211. [CrossRef]

2. Merz E. Surface reconstruction of a fetus $(28+2 \mathrm{GW})$ using HDlive technology. Ultraschall Med 2012; 33: 21.

3. Kurjak A, Pooh RK, Merce LT, Carrera JM, Salihagic-Kadic A, Andonotopo W. Structural and functional early human development assessed by three-dimensional and four-dimensional sonography. Fertil Steril 2005; 84: 1285-99. [CrossRef]

4. Tonni G, Grisolia G, Sepulveda W. Second trimester fetal neurosonography: reconstructing cerebral midline anatomy and anomalies using a novel three-dimensional ultrasound technique. Prenat Diagn 2014; 34: 75-83. [CrossRef]

5. Tonni G, Lituania M. OmniView algorithm: a novel 3-dimensional sonographic technique in the study of the fetal hard and soft palates. J Ultrasound Med 2012; 31: 313-8.

6. Rizzo G, Capponi A, Pietrolucci ME, Capece A, Aiello E, Mammarella $\mathrm{S}$, et al. An algorithm based on OmniView technology to reconstruct sagittal and coronal planes of the fetal brain from volume data sets acquired by three-dimensional ultrasound. Ultrasound Obstet Gynecol 2011; 38: 158-64. [CrossRef]

7. Grisolia G, Tonni G. Fetal echocardiography using HDlive. J Obstet Gynaecol Can 2013; 35: 497-8. [CrossRef]

8. Tonni G, Grisolia G. Fetal uvula: navigating and lightening the soft palate using HDlive. Arch Gynecol Obstet 2013; 288: 239-44. [CrossRef]

9. Araujo Júnior E, Nardozza LM, Nowak PM, Rolo LC, Guimarães Filho HA, Moron AF. Three-dimensional power Doppler placental vascularization indices in early pregnancy. A pilot study. J Obstet Gynaecol 2011; 31: 283-5. [CrossRef]

10. Pooh RK, Kurjak A. Novel application of three-dimensional HDlive imaging in prenatal diagnosis from the first trimester. J Perinat Med 2015; 43: 147-58. [CrossRef]

11. Hata T, Mashima M, Ito M, Uketa E, Mori N, Ishimura M. Threedimensional HDlive rendering images of the fetal heart. Ultrasound Med Biol 2013; 39: 1513-7. [CrossRef]

12. Kagan KO, Pintoffl K, Hoopmann M. First-trimester ultrasound images using HDlive. Ultrasound Obstet Gynecol 2011; 38: 607. [CrossRef]

13. Hata T. HDlive rendering image at 6 weeks of gestation. J Med Ultrason 2013; 40: 495-6. [CrossRef]

14. Bonilla-Musoles F, Raga F, Castillo JC, Bonilla FJr, Climent MT, Caballero O. High definition real-time ultrasound (HDlive) of embryonic and fetal malformations before week 16. Donald School J Ultrasound Obstet Gynecol 2013; 7: 1-8. [CrossRef]

15. Hata T, Tanaka H, Mashima M, Kanenishi K, Marumo G. HDlive for assessment of placenta and umbilical cord. Donald School J Ultrasound Obstet Gynecol 2014; 8: 391-9. [CrossRef]

16. Kanenishi K, Nitta E, Mashima M, Hanaoka U, Koyano K, Tanaka $\mathrm{H}$, et al. HDlive imaging of intra-amniotic umbilical vein varix with thrombosis. Placenta 2013; 34: 1110-2. [CrossRef]

17. AboEllail MA, Kanenishi K, Mori N, Kurobe A, Hata T. HDlive imaging of circumvallate placenta. Ultrasound Obstet Gynecol 2015; 46: 513-4. [CrossRef]
18. AboEllail MAM, Hanaoka U, Numoto A, Hata T. HDlive imaging of a giant fetal hemangioma. J Ultrasound Med 2015; 34: 2315-8. [CrossRef]

19. Hata T, Aoki S, Manabe A, Hata K, Miyazaki K. Three-dimensional ultrasonography in the first trimester of human pregnancy. Hum Reprod 1997; 12: 1800-4. [CrossRef]

20. Benoit B, Hafner T, Kurjak A, Kupesić S, Bekavac I, Bozek T. Threedimensional sonoembryology. J Perinat Med 2002; 30: 63-73. [CrossRef]

21. Harris RD, Couto C, Karpovsky C, Porter MM, Ouhilal S. The chorionic bump: a first-trimester pregnancy sonographic finding associated with a guarded prognosis. J Ultrasound Med 2006; 25: 757-63.

22. Hata T, Fujiwara T, Ishibashi M, Kuwamura E, Tenkumo C, Ishihara G. Antenatal three-dimensional sonographic features of placental shelf. J Med Ultrason 2012; 39: 43-4. [CrossRef]

23. Hata T, Hanaoka U, Tenkumo C, Sato M, Tanaka H, Ishimura M. Three-and four-dimensional HDlive rendering images of normal and abnormal fetuses: pictorial essay. Arch Gynecol Obstet 2012; 286: 1431-5. [CrossRef]

24. Hata T, Hanaoka U, Tenkumo C, Ito M, Uketa E, Mori N, et al. Threedimensional HDlive rendering image of cystic hygroma. J Med Ultrason 2013; 40: 297-9. [CrossRef]

25. Tenkumo C, Tanaka H, Ito M, Uketa E, Morin N, Hanaoka U, et al. Three-dimensional HDlive rendering images of the TRAP sequence in the first trimester: reverse end-diastolic umbilical artery velocity in a pump twin with an adverse pregnancy outcome. J Med Ultrason 2013; 40: 293-6. [CrossRef]

26. Bonilla-Musoles F, Machado LE, Rega F, Osborne NG. Fetus acardius two-and three-dimensional ultrasonographic diagnoses. J Ultrasound Med 2001; 20: 1117-27.

27. Bornstein E, Monteagudo A, Dong R, Schwartz N, Timor-Tritsch IE. Detection of twin reversed arterial perfusion sequence at the time of first-trimester screening. J Ultrasound Med 2008; 27: 1105-9.

28. Hata T, Kanenishi K, Hanaoka U, Uematsu R, Marumo G, Tanaka $\mathrm{H}$. HDlive study of fetal development and behavior. Donald School J Ultrasound Obstet Gynecol 2014; 8: 250-65. [CrossRef]

29. Hata T, Kanenishi K, Hanaoka U, AboEllail MA, Marumo G. HDlive and $4 \mathrm{D}$ ultrasound in the assessment of twin pregnancy. Donald School J Ultrasound Obstet Gynecol 2015; 9: 51-60. [CrossRef]

30. Hata T, Uketa E, Tenkumo C, Hanaoka U, Kanenishe K, Tanaka H. Three-and four-dimensional HDlive rendering image of fetal acrania/exencephaly in early pregnancy. J Med Ultrason 2013; 40: 271-3. [CrossRef]

31. Hata T, Hanaoka U, Uematsu R, Marumo G, Tanaka H. HDlive in the assessment of fetal facial abnormalities. Donald School J Ultrasound Obstet Gynecol 2014; 8: 344-52. [CrossRef]

32. Hanaoka U, Tanaka H, Koyano K, Uematsu R, Kanenishi K, Hata T. HDlive imaging of the face of fetuses with autosomal trisomies. J Med Ultrasonics 2014; 41: 339-42. [CrossRef]

33. Hata T, Hanaoka U, Mashima M. HDlive rendering image of cyclopia and a proboscis in a fetus with normal chromosomes at 32 weeks of gestation. J Med Ultrason 2014; 41: 109-10. [CrossRef]

34. Merz E. Surface reconstruction of a fetus $(28+2 \mathrm{GW})$ using HDlive technology. Ultraschall Med 2012; 33: 211-2. [CrossRef]

35. Gilbert-Barnes E, Debich-Spicer D. Embryo and Fetal Pathology. Cambridge University Press: New York; 2004. p. 216-28. [CrossRef]

36. Förster A. Die Missbildungen des Menschen systematisch dargestellt, nebst einem. Atlas. 2 Ausg. Friedrich Manke, 1865, Jena.

37. Allen LM, Silverman RK. Prenatal ultrasound evaluation of fetal diastematomyelia: two cases of type I split cord malformation. Ultrasound Obstet Gynecol 2000; 15: 78-82. [CrossRef]

38. Pang D. Split cord malformation: part II: clinical syndrome. Neurosurgery 1992; 31: 481-500. [CrossRef] 
39. Anderson NG, Jordan S, MacFarlane MR, Lovell-Smith M. Diastematomyelia: diagnosis by prenatal sonography. AJR Am J Roentgenol 1994; 163: 911-4.[CrossRef]

40. AboEllail MA, Hanaoka U, Mashima M, Kawanishi K, Hata T. HDlive image of fetal endocardial cushion defect. Donald School J Ultrasound Obstet Gynecol 2014; 8: 437-8. [CrossRef]

41. Pooh RK. 13-week pulmonary sonoangiogram by 3D HDlive flow. Donald School J Ultrasound Obstet Gynecol 2015; 9: 355-6. [CrossRef]

42. Pooh RK. First trimester scan by 3D, 3D HDlive and HDlive silhouette/flow ultrasound imaging. Donald School J Ultrasound Obstet Gynecol 2015; 9: 361-71. [CrossRef]

43. Bonilla-Musoles F, Bonilla F Jr, Raga F, Caballero O, Cadete C, Machado LE. Second trimester anomaly scan by $3 \mathrm{D} / 4 \mathrm{D}$ ultrasound. Donald School J Ultrasound Obstet Gynecol 2015; 9: 372-81. [CrossRef]

44. AboEllail MA, Kanenishi K, Marumo G, Masaoka H, Ejiri A, Hata T. Fetal HDlive silhouette mode in clinical practice. Donald School J Ultrasound Obstet Gynecol 2015; 9: 413-9. [CrossRef]

45. Hata T, Hanaoka U, Mashima M, Ishimua M, Marumo G, Kanenishi $\mathrm{K}$. Four-dimensional HDlive rendering image of fetal facial expression: a pictorial essay. J Med Ultrason 2013; 40: 437-41. [CrossRef]

46. Tanaka T, Ito M, Uketa E, Mori N, Hanaoka U, Kanenishi K, et al. Antenatal three-dimensional sonographic features of multicystic dysplastic kidney. J Med Ultrason 2013; 40: 181-3. [CrossRef]

47. Cajusay-Velasco S, Hata T. HDlive in the assessment of fetal intracranial, intra-thoracic, and intra-abdominal anomalies. Donald School J Ultrasound Obstet Gynecol 2014; 8: 362-75. [CrossRef]

48. AboEllail MA, Tanaka H, Mori N, Tanaka A, Kubo H, Shimono R, et al. HDlive imaging of meconium peritonitis. Ultrasound Obstet Gynecol 2015; 45: 494-6. [CrossRef]
49. AboEllail MA, Tanaka H, Mori N, Hanaoka U, Hata T. HDlive silhouette mode in antenatal diagnosis of jejunal atresia. Ultrasound Obstet Gynecol 2015 [ahead of print].

50. Kaji T, Maeda K, Hichijo A, Takahashi Y, Nakayama S, Irahara M. Three-dimensional HDlive rendering image of the fetal perineum in anorectal atresia. Ultrasound Obstet Gynecol 2015 [ahead of print].

51. Ishibashi M, Tanaka H, Ito M, Uketa E, Mori N, Hanaoka U, et al. Antenatal three-dimensional sonographic diagnosis of persistent cloaca. J Med Ultrason 2013; 40: 275-7. [CrossRef]

52. Grigore M, Mareş A. The role of HDlive technology in improving the quality of obstetrical cerebral midline anatomy and anomalies using a novel three-dimensional ultrasound technique. Prenat Diagn 2014; 34: 75-83. [CrossRef]

53. Grigore M, Mareş A. The role of HDlive technology in improving the quality of obstetrical images. Med Ultrason 2013; 15: 209-14. [CrossRef]

54. Araujo Júnior E, Santana EF, Nardozza LM, Moron AF. Assessment of embryo/fetus during pregnancy by three-dimensional ultrasonography using the HD live software: iconographic essay. Radiol Bras 2015; 48: 52-5. [CrossRef]

55. Dall'Asta A, Paramasivam G, Lees CC. Crystal vue technique for imaging of the fetal spine and ribs. Ultrasound Obstet Gynecol 2016; 47: 383-4. [CrossRef]

56. Bonilla-Musoles F, Raga F, Osborne NG, Bonilla F Jr, Caballero O, Climent MT, et al. Multimodality 3-dimendional volumetric ultrasound in obstetrics and gynecology with an emphasis in HDlive technique. Ultrasound Q 2013; 29: 1-13. [CrossRef] 